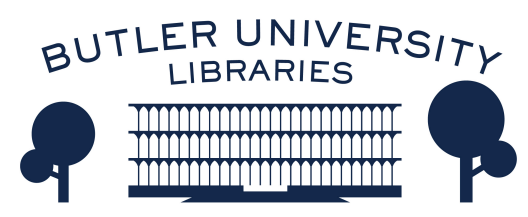

Journal of Hindu-Christian Studies

Volume 7

Article 16

January 1994

\title{
Book Review: "Encountering God: A Spiritual Journey from Bozeman to Banaras"
}

Harold Coward

Follow this and additional works at: https://digitalcommons.butler.edu/jhcs

Part of the Religion Commons

\section{Recommended Citation}

Coward, Harold (1994) "Book Review: "Encountering God: A Spiritual Journey from Bozeman to Banaras"," Journal of Hindu-Christian Studies: Vol. 7, Article 16.

Available at: https://doi.org/10.7825/2164-6279.1104

The Journal of Hindu-Christian Studies is a publication of the Society for Hindu-Christian Studies. The digital version is made available by Digital Commons @ Butler University. For questions about the Journal or the Society, please contact cbauman@butler.edu. For more information about Digital Commons @ Butler University, please contact digitalscholarship@butler.edu. 
and thus posed a serious challenge to his dream of Christianizing India. In spite of that he remained hopeful of the advent of India into the Church, although his vision of India rediscovering itself in a Christianized form faded considerably.

This is a carefully researched, well-written scholarly book which deserves to be recognized as the standard work on Monchanin's life. Careful use is made of Monchanin's letters and essays, many of which are in French. Rodhe includes a helpful English summary of some of these writings in Chapter 10. Also included is a concise annotated listing of writing about Monchanin. For those interested in the main publication coming out of the ashram, "An Indian Benedictine Ashram", which was published in English and French with several revisions, chapter 8 offers a close reading and critical literary analysis of the text. The work states the main aim of the ashram as the reception and preparation of Indian monks to stand before God in prayer and adoration in the name of a Christianized India. (p.54) However, notes Rodhe, "To their disappointment these monks never arrived" (p.54). Monchanin's health declined rapidly in 1957 due to cancer. He died in Paris that year realizing that his vision of a Christianized India had not even begun to be realized, and perhaps never would be. But he also saw himself as like Moses who died before entering the promised land yet hopeful that others would go on where he had not succeeded. Toward himself he was ruthless in his determination to live as an Indian, under an Indian bishop, and not under any kind of European mission venture. In this he was unique and successful. He had a brilliant mind and a deep mystical vision but one that due to his poor command of Tamil and English he rarely was able to communicate to those around him.

Of Monchanin Bede Griffiths said, "he has left behind him the witness to an ideal, like that of de Nobili and Brahmabandhav Upadhyaya, which it seems to me can only grow in its significance as the years go by." (p.64) Rodhe concludes, "Monchanin was a pioneer in the Catholic Church of an inclusive view of the relation between Christianity and Hinduism. The Indian tradition should not be rejected but integrated in the Church." (p.73) Something of Monchanin's contribution may be seen in the fact that after his death this view became the official position of the Catholic Church at the Second Vatican Council.

\section{Harold Coward \\ University of Victoria}

\section{Note}

1. B.R. Ambedkar, "Annihilation of Caste" (New Delhi: Arnold Pub., 1990). Letters between Gandhi and Ambedkar are included in the book.

Encountering God: A Spiritual Journey from Bozeman to Banaras. Diana Eck. Boston: Beacon Press, 1993, pp.xv +259.

SELDOM DO WE read a book that lifts us to new levels of understanding - a book that evokes the complexity of the Hindu-Christian encounter so fully and sensitively that we are surprised and inspired by a fresh recognition of our own lives in its words. Encountering God is such a book. Perhaps Diana Eck's new book had such a profound impact upon me because of the close parallel of my experience with hers. Beginning life from a deeply spiritual Christian boyhood in the remote foothills of the Canadian
Rockies (less than 300 miles North of Diana Eck's childhood home of Bozeman, Montana), I soon had my strong but naive Christianity challenged, broadened and deepened as I studied Hindu philosophy with Professor T.R.V. Murti at Banaras. Now, many years later I seek, within the evolving context of that encounter, an adequate expression for the religious pluralism of our modern world. While previous books by Wilfrid Smith, John Hick, Paul Knitter and Raimundo Panikkar have moved us forward, 
Diana Eck's carefully constructed conception of pluralism is the most theoretically satisfying and the most convincing in its practical grounding that I have encountered to date. There is no separation between theory and practice here, for what is offered is an open and honest spiritual biography in which the essential aspects of Christian life are found to resonate with those of Hinduism in theology and worship as well as at crisis points of life such as unexplainable suffering and death. A most attractive aspect of Eck's book is the ease and naturalness with which she moves back and forth between intimate lived experience and careful academic reflection. In this sense her style shares with the best of women's writing in rejecting the artificial separation between rigorous critical reflection and so-called subjective experience. It is a welcome and enlivening genre for serious academic writing on interreligious dialogue, and those of us who are men must thank our women colleagues for courageously showing us the way.

Eck defines interfaith dialogue as the mutual questioning and listening that arises in the different communities and contexts of our daily life - "the dialogue of life" (p.16) in which one experiences a two-way discourse of "mutual witness" (listening and speaking) and "mutual transformation" (understanding oneself through the other). After imaginatively situating this dialogue in present-day North America (Chapter 2), we share in Diana's encounter of God through the names and forms of other traditions, especially Hinduism (Chapter 3 ). This is a rich and stimulating chapter in which the Christian (and Muslim and Jewish) stress on the oneness of God is placed in a counterpoint with Hindu conceptions of the ONE manifesting itself in many forms and names - as many as are needed to reach all beings. The limits of darshana or points of view in fully "seeing" God, and of speech or language in exhaustively expressing God are explored, and the power of such limited images and descriptions to serve as windows to God is demonstrated. For Eck the interfaith experience of seeing God through a "Hindu window" such as the image of Vishnu at Padmanabhaswamy both challenged and enlarged her own concept of God. She says:
Seeing that triptych in the temple in Trivandrum, with its three glimpses of God larger than one could fully comprehend, was a moment of recognition for me, and the experience of God's presence there was describable only as worship. My experience as a Christian was surely different from that of the Hindus pressed against me on either side. But we shared the sense of delight and revelation as the doors were opened, and perhaps some sense of both the majesty and mystery of the Divine. (p.79)

Yet for her as a Christian, "it is Christ who enables Christians ... to recognize God especially where we don't expect to do so, and where it is not easy to do so" (p.79). In Eck's experience it is through such interfaith experience that our recognition of God becomes larger and clearer.

Chapter 4 continues this theological dialogue through explorations of Christian notions of Christ as incarnation with Hindu ideas of avatāras. Once again the Christian focus on the one - the uniqueness of Christ - is placed in counterpoint with the Hindu view of the many faces of the one God. Eck's analysis is especially rich, offering comparative insights that are not found elsewhere. Chapter 5 focuses on the breath of God, Holy Spirit for Christians, and präna / sakti, the life-force, for the Hindu. As in the previous chapter, the comparisons made are original, resulting in new insights for the reader.

Westerners are often drawn to Eastern religions because of the practical effectiveness and discipline of their meditative teachings. This fascination is engaged in . Chapter 6 which Eck perceptively titles "Attention to God". Christians are reminded of the request of Jesus to his followers to "watch with me" (in the garden of Gethsemane). The Christian sense of "watching with others" in times of suffering or crisis is fruitfully related to Eastern forms of meditation. In this context the current popularity of the term "spirituality" rather than "religion" is considered.

For students of dialogue and religious pluralism, Chapter 5 "Is Our God Listening: Exclusivism, Inclusivism and Pluralism" is the heart of the book. Here Eck presents her own 
theory of "pluralism". While her accounts of "exclusivism" and "inclusivism" offer nothing new, Eck's analysis of "pluralism" as contrasted with "plurality", or mere diversity, does contain fresh insights - insights that I found described my own Christian viewpoint more fully than had my own previous attempts. Under the evocative hymn phrase "There's a Wideness in God's Mercy", Eck suggests that Christians go beyond Karl Rahner's notion of "anonymous Christians" to a recognition of the wideness of God's mercy as extending beyond any one tradition and embracing all. As she puts it, "The boundaries of our various traditions need not be the places where we halt and contend over our differences, but might well be places where we meet and catch a glimpse of glory as seen by another" (p.186). This does not mean that we give up speaking in our own theological language, but that we speak our theology, sensitively, in the hearing of others. The image this evokes for me is one in which we are all seated around a large table in an old-fashioned farm kitchen speaking sincerely, openly and honestly to one another of our religions - as fellow members of the world's spiritual family. Eck, in fact, employs the term "The World House" in her practical understanding of pluralism. This she delineates under four points. (1) Pluralism differs from plurality or the mere fact of diversity by demanding our active engagement with each other. We cannot be passive observers. (2) Pluralism is not simply tolerance but requires that I seek to understand my neighbour of another religion. While passive tolerance may be easy, understanding requires hard work and openness to growth. (3) Pluralism differs from relativism in that it involves real commitment. Eck's discussion of this point, perhaps the most important one for those of us living in modern societies, is brilliant and dead on the mark. Public policy in modern societies usually attempts to deal with problems of plurality by invoking a relativist solution which fails to take commitment seriously. This section (pp.193-6) should be required reading for politicians and civil servants. Because of his or her commitment the religious pluralist is not generic or neutral but stands in a particular community, e.g. a Christian pluralist, a Hindu pluralist, etc., "all daring to be themselves, not in isolation from but in relation to one another. [...] The challenge for the pluralist is commitment without dogmatism and community without communalism." (p.195) Rather than neutralizing commitment, pluralism creates the space within which the encounter of commitments occurs. Such an encounter is a radically open, critical and self-critical experience of dialogue. The fourth and fifth points follow naturally. (4) Pluralism is not syncretism, but is based on respect for difference; and (5) Pluralism is based on interreligious dialogue, a dialogue of real encounter. Such a dialogue is authentically presented to us in the thinking and life experience of Diana Eck as Encountering God. It is a book for students, theologians or any sincere seeker in today's world.

Harold Coward University of Victoria 